\title{
PEMETAAN PALANG MERAH REMAJA (PMR) DI KOTA PADANG
}

\author{
Noveri Yarmansyah ${ }^{1,}$ Yurni Suasti ${ }^{2}$ \\ Program Studi Pendidikan Geografi \\ Fakultas Ilmu Sosial Universitas Negeri Padang \\ e-mail : acingzafran@gmail.com
}

\begin{abstract}
Abstrak
Penelitian ini bertujuan untuk mengetahui persebaran Palang Merah remaja, Kegiatan Palang Merah Remaja SMP/MTs dan SMA / SMK / MAN di Kota Padang. Penelitian ini adalah penelitian deskriftif. Data dikumpulkan melalui survey lapangan dan wawancara. Teknik analisis data yaitu menggunakan aplikasi (software) Sistem Informasi Geografi yaitu Arcgis 10.1. Penelitian ini memperoleh : (1) peta sebaran Palang Merah Remaja (PMR), pada tingkat SMA/SMK/MAN terdapat 34 titik sekolah yang memiliki PMR. Sedangkan pada tingkat SMP/MTs terdapat 23 titik sekolah yang memiliki PMR. (2) kegiatan Palang Merah Remaja (PMR) SMP/MTS dan SMA/SMK/MAN di Kota Padang. Pada tingkat SMP/MTs terdapat 15 sekolah yang aktif kegiatan PMR nya dan terdapat 8 sekolah yang kegiatannya tidak aktif. kegiatan PMR pada tingkat SMP semuanya sama yaitu: PAB, Diklat, Latihan Gerakan, Mubes, Pelantikan Pengurus, Ltihan Mingguan, Kepemimpinan kesiapsiagaan bencana, PK. Pada tingkat SMA/SMK/MAN terdapat 29 sekolah yang aktif kegiatan PMR nya, dan 5 sekolah yang kegiatannya tidak aktif adapun kegiatan nya antara lain PAB, Diklat,Latihan Pendalaman, Mubes, Pelantikan Pengurus, Pelantikan anggota, TDO, Lomba Oasis, Lomba Jumbara, Latihan Gabungan, Simulasi Gabungan, Donor Darah, Tim Medis, Bakti Sosial, Pertolongan Pertama.
\end{abstract}

Kata Kunci: Pemetaan, Palang Merah Remaja, Padang

\begin{abstract}
This study aims to view about distrbution all of Youth Red Cross in Padang City, and the activities of the Youth Red Cross (PMR) of JHS / MTS and SHS / VHS / MAN in Padang City. This study use quantitative approach. Data collection tools use field surveys, interviews. Data analysis techniques are used, first, by using Global Positioning System (GPS) and processed using the Geographic Information System (software) application, Arcgis 10.1. The results showed that: (1) the Youth Red Cross (PMR) distribution map, at the level of SMA / SMK / MAN there were 34 school points that had PMR. There are 23 school / junior high school / junior high school level points that have PMR. (2) the activities of the Junior Red Cross (PMR) of SMP / MTS and SMA / SMK / MAN in Padang City. At the SMP / MTs level there are 15 schools that are active in PMR activities and there are 8 schools whose activities are not active. PMR activities at the junior high school level are all the same: registration of new members, Education and Training, Exercise Movement, Great Deliberations, Inauguration of Administrators, Weekly Exercises, Disaster Preparedness Leaders, Family Equipment. At the SMA / SMK / MAN level there are 29 schools that are active in their teenage Red Cross activities. And 5 schools whose activities are not active as for their activities include registration of new members, Education and Training, Deepening Training, Large Deliberations, Inauguration of Administrators, Inauguration of members, Basic training of organizations, Oasis Contest, Happy Service Meeting Competition, Joint Training, Combined Simulation, Blood Donors, Medical Team, Social Service, First Aid.
\end{abstract}

\section{Keywords: Mapping, Youth Red Cross, Padang}

1. Mahasiswa Program Studi Pendidikan Geografi, Fakultas Ilmu Sosial

2. Dosen Jurusan Geografi, Fakultas Ilmu Sosial 


\section{PENDAHULUAN}

Kota Padang sebagai daerah rawan bencana alam. Bencana bisa menyebabkan kematian, korban luka-luka, rusaknya bangunan, sekolah, masjid dan infrastruktur lainya. Sangat penting bagi kita mempunyai daya tahan dalam menghadapi ancaman, misalnya mengetahui tanda-tanda bencana, akibat dari bencana, dan pertolongan pertama setelah terjadi bencana. Oleh sebab itu untuk tingkatan sekolah perlu adanya program ekstrakurikuler untuk meningkatkan pemahaman atau kemampuan dan karakter siswa terkait dengan pertolongan pertama dan jiwa sukarelawan.

Salah satu kegiatan ekstrakurikuler yang menekankan nilai karakter pada siswa, yaitu kegiatan ekstrakurikuler Palang Merah Remaja yang berkaitan dengan dimensi sosial, dan merupakan salah satu kegiatan yang bergerak dalam bidang kemanusiaan. (Utami, 2010: 3).

Kegiatan yang diadakan Palang Merah Remaja meliputi kegiatan donor darah, bakti sosial, memberikan sumbangan pada korban bencana alam dan lain sebagainya. Siswa diajak terjun langsung dalam masyarakat, agar siswa dapat merasakan bahwa kepedulian terhadap sesama merupakan hal yang sangat positif dilakukan. Melalui kegiatan Palang Merah Remaja, proses penyerapan nilai-nilai kemanusiaan dapat dicerna oleh siswa dengan rasa, hati nurani, akal dan kehendaknya untuk berbuat baik. Sehingga dengan pengelolaan jiwanya, siswa mempunyai sikap dan perbuatan yang dapat menjunjung tinggi harkat dan martabat manusia. (Reren Eko Prahesty. 2016;3)

Kegiatan PMR memiliki banyak dampak positif bagi siswa maupun sekolah. Dampak positif bagi siswa yaitu; menambah pengetahuan dan pengalaman anak dalam kegiatan kepalangmerahan, menumbuhkan keberanian anak untuk memberikan pertolongan pertama ketika terjadi kecelakaan, mengubah persepsi anak-anak untuk tidak takut ketika ada ambulans yang melintas, menumbuhkan kepedulian sosial anak melalui bakti sosial maupun gotong royong, dan kegiatan PMR sebagai wadah untuk anak memperoleh prestasi. (Dani Pratomo. 2018).

\begin{tabular}{ccc}
\multicolumn{2}{c}{ Adanya Palang } & Merah \\
Ramaja & (PMR) & sangat
\end{tabular}
menguntungkan bagi sekolah karena selain dapat mebentuk karakter siswa juga berfungsi sebagai tempat mengasaah sofskill siswa yang tidak didapat oleh siswa saat jam pelajaran seperti materi pertolongan pertama bencana serta menanamkan jiwa sukarelawan dan juga bisa untuk mengurangi risiko bencana.

Berdasarkan informasi dari Forum Remaja Palang Merah Indonesia (FORPIS) Kota Padang tidak semua sekolah memiliki Palang 
Merah Remaja (PMR) dan tidak semua Palang Merah Remaja (PMR) aktif dalam berkegiatan.

Tujuan penelitian ini adalah untuk mengetahui peta sebaran Palang Merah Remaja (PMR) SMP/MTS dan SMA/SMK/MAN di Kota Padang dan mengetahui kegiatan Palang Merah Remaja (PMR) SMP/MTS dan SMA/SMK/MAN di Kota Padang.

\section{METODE PENELITIAN}

Jenis penelitian ini adalah penelitian deskriptif. Peneliti di lakukan disekolah yang memiliki PMR di Kota Padang. Populasi penelitian ini adalah Sekolah SMP/ MTS dan SMA/MA yang memiliki PMR berjumlah 57 Unit. Data peneitian terdiri dari titik koordinat
PMR dan data kegiatan PMR. Titik koordinat PMR didapatkan melalui survey lapangan menggunakan GPS dan kegiatan PMR melalui wawancara yang menggunakan kuisioner. Teknik analisis data yang digunakan dalam penelitian ini adalah analisis tetangga terdekat atau Nearest Neighbour Analyst (NNA) dan analisis persentase.

\section{HASIL DAN PEMBAHASAN}

1. Persebaran Palang Merah Remaja (PMR) Di Kota Padang

Persebaran PMR di Kota Padang dapat dilihat pada gambar 1. Dari gambar 1 terlihat bahwa PMR di Kota Padang terdapat hampir diseluruh Kecamatan yang ada di Kota Padang.

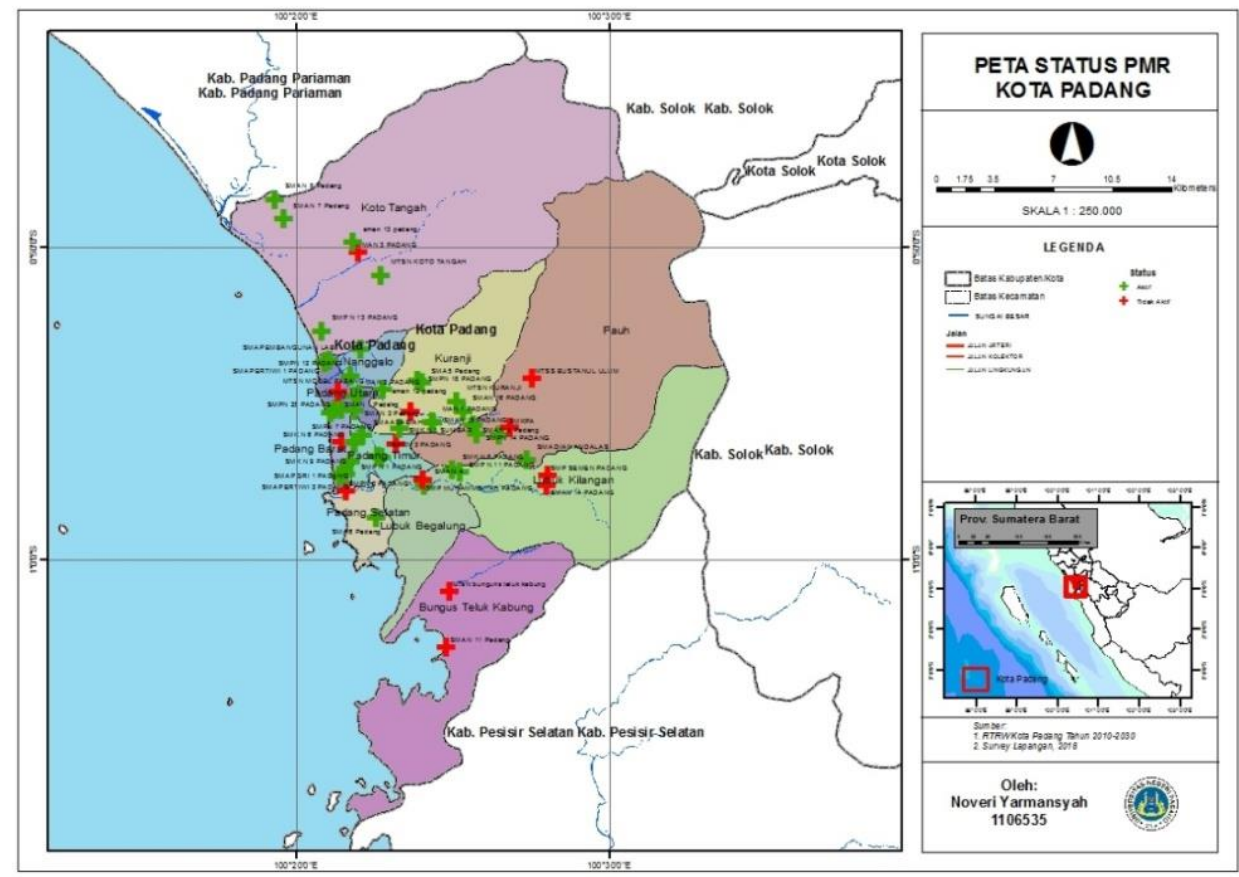

Gambar 1. Peta Sebaran Status PMR di Kota Padang Sumber: Hasil Olahan Data Penelitian, 2018 
Selanjutnya dapat ditentukan Nearest Neighbour Analyst pola persebaran PMR di Kota menggunakan ArcGIS. Hasil yang Padang, dengan menggunakan diperoleh adalah sebagai berikut: Analisis Tetangga Terdekat atau

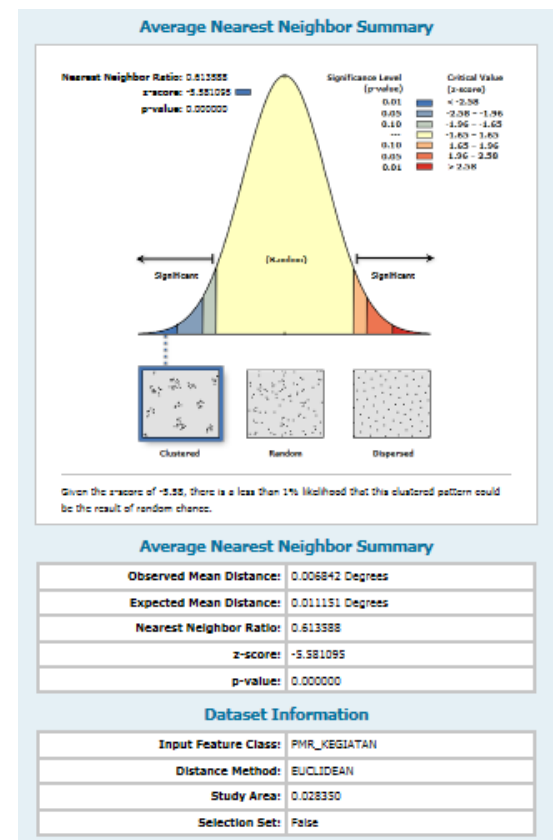

Gambar 2. Analisis Tetangga Terdekat PMR di-Kota Padang Sumber: Hasil Olahan Data Penelitian, 2018

Besarnya jarak terdekat di setiap lokasi PMR diperoleh dengan Nearest Neighbour Analyst (NNA) adalah 0.613588, yang berarti bahwa rasio dari Analisis Tetangga Terdekat berada pada kisaran angka $0 \quad-\quad 1.00$. angka ini menunjukkanbahwa pola persebaran PMR di Kota Padang termasuk pola mengelompok.

\section{Kegiatan PMR pada Sekolah Menengah Pertama dan}

Sekolah Menengah Atas di Kota Padang di Kota Padang Status dan kegiatan PMR di Kota Padang dapat dikelompokkan atas dua bagian, yang pertama PMR pada Sekolah Menengah Pertama dan PMR di Sekolah Menengah Atas. 
Tabel 1. Status PMR pada SMP/MTs di Kota Padang

\begin{tabular}{lllll}
\hline No & Status PMR & \multicolumn{1}{c}{ Nama Sekolah } & \multicolumn{2}{c}{ Jumlah } \\
\cline { 3 - 5 } & & & Total & \% \\
\hline 1 & Aktif & SMPN 1, SMPN 7, SMPN 11, SMPN 12, & 15 & $65,22 \%$ \\
& & SMPN 13, SMPN 14, SMPN 18, SMPN 25, & \\
& & SMPN 29, SMP Pembangunan LAB UNP, & \\
& & MTsN Koto Tangah, MTsN Durian Tarung, & \\
& & MTsN Model Padang, MTsN Kuranji, SMP & \\
\hline 2 & Tidak aktif & Kartika 1 - 7 Padang & $34,78 \%$ \\
& & SMPN 3 Padang, SMPN 31, SMP Semen & \\
& & Padang, SMP IT Adzkia, SMP Muhammadyah & \\
& 6 Padang, MTsN Bungus Teluk Kabung, MTsN & \\
\hline & Bustanul Ulum, SMP Al- Azhar Padang & $\mathbf{1 0 0 \%}$ \\
\hline
\end{tabular}

Sumber: Analisa Pribadi, 2018

Tabel 2. Status PMR pada SMA/MA/SMK di Kota Padang

\begin{tabular}{|c|c|c|c|c|}
\hline \multirow[t]{2}{*}{ No } & \multirow[t]{2}{*}{ Status PMR } & \multirow{2}{*}{ Nama Sekolah } & \multicolumn{2}{|c|}{ Jumlah } \\
\hline & & & Total & $\%$ \\
\hline 1 & Aktif & $\begin{array}{l}\text { SMAN 1, SMAN 3, SMAN 4, SMAN 6, } \\
\text { SMAN 7, SMAN 8, SMAN 9, SMAN 10, } \\
\text { SMAN 12, SMAN 13, SMAN 16, SMA } \\
\text { Pertiwi 1, SMA, Pertiwi II, SMA Kartika 1-5, } \\
\text { SMA Pembangunan LAB UNP, SMA } \\
\text { DONBOSCO, SMA Adabiah I, SMA Adabiah } \\
\text { II, SMA PGRI I, SMA Andalas, SMKN 2, } \\
\text { SMKN 6, SMKN 8, SMKN 9, SMAK Padang, } \\
\text { MAN 1, MAN 2, SMKN I Sumbar }\end{array}$ & 29 & $85,30 \%$ \\
\hline 2 & Tidak aktif & $\begin{array}{l}\text { SMAN } 11, \text { SMAN } 4, \text { SMAN } 15, \text { MAN } 3 \text {, } \\
\text { SMA Taruna }\end{array}$ & 5 & $14,70 \%$ \\
\hline
\end{tabular}

Sumber: Analisa Pribadi, 2018

Tabel 3. Jenis Kegiatan PMR pada SMP/MTs di Kota Padang

\begin{tabular}{lllll}
\hline No. & \multicolumn{1}{c}{ Jenis Kegiatan } & \multicolumn{1}{c}{ Sekolah } & \multicolumn{2}{c}{ Jumlah } \\
\cline { 3 - 5 } & & & Total & \% \\
\hline 1. & PAB, Diklat,Latihan & SMPN 1, SMPN 7, SMPN 11, 15 & $100 \%$ \\
Gerakan, Mubes, & SMPN 12, SMPN 13, SMPN & \\
Pelantikan Pengurus, & 14, SMPN 18, SMPN 25, & \\
Ltihn Mingguan, & SMPN 29, SMP Pembangunan & \\
Kepemimpinan & LAB UNP, MTsN Koto & \\
kesiapsiagaan & Tangah, MTsN Durian Tarung, & \\
bencana,PK & MTsN Model Padang, MTsN & \\
& Kuranji, SMP Kartika 1 - 7 & \\
& Padang & & \\
\hline
\end{tabular}

Sumber: Analisa Pribadi, 2018 
Tabel 4. Jenis Kegiatan PMR pada SMA/MA/SMK di Kota Padang

\begin{tabular}{|c|c|c|c|c|}
\hline \multirow[b]{2}{*}{ No } & \multirow[b]{2}{*}{ Jenis Kegiatan } & \multirow[b]{2}{*}{ Sekolah } & \multicolumn{2}{|c|}{ Jumlah } \\
\hline & & & Total & $\%$ \\
\hline 1 & PAB & $\begin{array}{l}\text { SMAN 1, SMAN 3, SMAN 4, SMAN 6, } \\
\text { SMAN 7, SMAN 8, SMAN 9, SMAN 10, } \\
\text { SMAN 12, SMAN 13, SMAN 16, SMA } \\
\text { Pertiwi 1, SMA, Pertiwi II, SMA Kartika } 1 \\
\text { - 5, SMA Pembangunan LAB UNP, SMA } \\
\text { DONBOSCO, SMA Adabiah I, SMA } \\
\text { Adabiah II, SMA PGRI I, SMA Andalas, } \\
\text { SMKN 2, SMKN 6, SMKN 8, SMKN 9, } \\
\text { SMAK Padang, MAN 1, MAN 2, SMKN I } \\
\text { Sumbar }\end{array}$ & 29 & $100 \%$ \\
\hline 2 & Diklat & $\begin{array}{l}\text { SMAN 1, SMAN 3, SMAN 4, SMAN 6, } \\
\text { SMAN 7, SMAN 8, SMAN 9, SMAN 10, } \\
\text { SMAN 12, SMAN 13, SMAN 16, SMA } \\
\text { Pertiwi 1, SMA, Pertiwi II, SMA Kartika } 1 \\
\text { - 5, SMA Pembangunan LAB UNP, SMA } \\
\text { DONBOSCO, SMA Adabiah I, SMA } \\
\text { PGRI I, SMA Andalas, SMKN 2, SMKN } \\
\text { 6, SMKN 8, SMKN 9, SMAK Padang, } \\
\text { MAN 1, MAN 2, SMKN I Sumbar }\end{array}$ & 28 & $96,55 \%$ \\
\hline 3 & Latihan Pendalaman & $\begin{array}{l}\text { SMAN 1, SMAN 3, SMAN 4, SMAN 6, } \\
\text { SMAN 8, SMAN 12, SMAN 13, SMAN } \\
\text { 16, SMA Pertiwi 1, SMA, Pertiwi II, SMA } \\
\text { Kartika } 1 \text { - 5, SMA Pembangunan LAB } \\
\text { UNP, SMA DONBOSCO, SMA Adabiah } \\
\text { I, SMA Adabiah II, SMA PGRI I, SMA } \\
\text { Andalas, SMKN 2, SMKN 6, SMKN 8, } \\
\text { SMKN 9, MAN 1, MAN 2, SMKN I } \\
\text { Sumbar }\end{array}$ & 25 & $86,20 \%$ \\
\hline 4 & Mubes & $\begin{array}{l}\text { SMAN 1, SMAN 3, SMAN 4, SMAN 6, } \\
\text { SMAN 7, SMAN 8, SMAN 10, SMAN 12, } \\
\text { SMAN 13, SMAN 16, SMA Pertiwi 1, } \\
\text { SMA, Pertiwi II, SMA Kartika 1-5, SMA } \\
\text { Pembangunan LAB UNP, SMA } \\
\text { DONBOSCO, SMA Adabiah I, SMA } \\
\text { Adabiah II, SMA PGRI I, SMA Andalas, } \\
\text { SMKN 2, SMKN 6, SMKN 8, SMKN 9, } \\
\text { SMAK Padang, MAN 1, MAN 2, SMKN I } \\
\text { Sumbar }\end{array}$ & 28 & $96.55 \%$ \\
\hline & & $\begin{array}{l}\text { SMAN 1, SMAN 3, SMAN 4, SMAN 6, } \\
\text { SMAN 7, SMAN 8, SMAN 9, SMAN 10, } \\
\text { SMAN 12, SMAN 13, SMAN 16, SMA } \\
\text { Pertiwi 1, SMA, Pertiwi II, SMA Kartika } 1 \\
\text { - 5, SMA Pembangunan LAB UNP, SMA } \\
\text { DONBOSCO, SMA Adabiah I, SMA } \\
\text { Adabiah II, SMA PGRI I, SMA Andalas, } \\
\text { SMKN 2, SMKN 6, SMKN 8, SMKN 9, } \\
\text { SMAK Padang, MAN 1, MAN 2, SMKN I }\end{array}$ & & \\
\hline 5 & Pelantikan Pengurus & Sumbar & 29 & $100 \%$ \\
\hline 6 & Pelantikan Anggota & $\begin{array}{l}\text { SMAN 1, SMAN 3, SMAN 4, SMAN 6, } \\
\text { SMAN 7, SMAN 8, SMAN 9, SMAN 10, } \\
\text { SMAN 12, SMAN 13, SMAN 16, SMA }\end{array}$ & 29 & $100 \%$ \\
\hline
\end{tabular}




\begin{tabular}{|c|c|c|c|c|}
\hline & & $\begin{array}{l}\text { Pertiwi 1, SMA, Pertiwi II, SMA Kartika } 1 \\
-5 \text {, SMA Pembangunan LAB UNP, SMA } \\
\text { DONBOSCO, SMA Adabiah I, SMA } \\
\text { Adabiah II, SMA PGRI I, SMA Andalas, } \\
\text { SMKN 2, SMKN 6, SMKN 8, SMKN 9, } \\
\text { SMAK Padang, MAN 1, MAN 2, SMKN I } \\
\text { Sumbar }\end{array}$ & & \\
\hline 7 & TDO & $\begin{array}{l}\text { SMAN 1, SMAN 6, SMAN 8, SMAN 9, } \\
\text { SMAN 12, SMAN 13, SMAN 16, SMA } \\
\text { Pertiwi 1, SMA, Pertiwi II, SMA Kartika } 1 \\
\text {-5, SMA Pembangunan LAB UNP, SMA } \\
\text { DONBOSCO, SMA Adabiah II, SMA } \\
\text { PGRI I, SMA Andalas, SMKN 2, SMKN } \\
\text { 6, SMKN 8, SMKN 9, SMAK Padang, } \\
\text { MAN 1, MAN 2, SMKN I Sumbar }\end{array}$ & 24 & $82,75 \%$ \\
\hline 8 & Lomba Oasis & $\begin{array}{l}\text { SMAN 1, SMAN 3, SMAN 4, SMAN 6, } \\
\text { SMAN 8, SMAN 9, SMAN 10, SMAN 12, } \\
\text { SMAN 13, SMAN 16, SMA Pertiwi 1, } \\
\text { SMA, Pertiwi II, SMA Kartika 1 - 5, SMA } \\
\text { Pembangunan LAB UNP, SMA } \\
\text { DONBOSCO, SMA Adabiah I, SMA } \\
\text { Adabiah II, SMA PGRI I, SMA Andalas, } \\
\text { SMKN 2, SMKN 6, SMKN 8, SMKN 9, } \\
\text { MAN 1, MAN 2, SMKN I Sumbar }\end{array}$ & 27 & $93,10 \%$ \\
\hline 9 & Lomba Jumbara & $\begin{array}{l}\text { SMAN 1, SMAN 3, SMAN 4, SMAN 6, } \\
\text { SMAN 7, SMAN 8, SMAN 9, SMAN 10, } \\
\text { SMAN 12, SMAN 13, SMAN 16, SMA } \\
\text { Pertiwi 1, SMA, Pertiwi II, SMA Kartika 1 } \\
\text {-5, SMA Pembangunan LAB UNP, SMA } \\
\text { DONBOSCO, SMA Adabiah I, SMA } \\
\text { Adabiah II, SMA PGRI I, SMA Andalas, } \\
\text { SMKN 2, SMKN 8, SMKN 9, SMAK } \\
\text { Padang, MAN 1, MAN 2, SMKN I } \\
\text { Sumbar }\end{array}$ & 28 & $96,55 \%$ \\
\hline 10 & Latihan Gabungan & $\begin{array}{l}\text { SMAN 1, SMAN 6, SMAN 8, SMAN 9, } \\
\text { SMAN 10, SMAN 12, SMAN 13, SMAN } \\
\text { 16, SMA Pertiwi 1, SMA, Pertiwi II, SMA } \\
\text { Kartika } 1 \text { - 5, SMA Pembangunan LAB } \\
\text { UNP, SMA DONBOSCO, SMA Adabiah } \\
\text { I, SMA Adabiah II, SMA PGRI I, SMA } \\
\text { Andalas, SMKN 2, SMKN 6, SMKN 8, } \\
\text { SMKN 9, SMAK Padang, MAN 1, MAN } \\
\text { 2, SMKN I Sumbar }\end{array}$ & 26 & $89,65 \%$ \\
\hline 11 & Simulasi Gabungan & $\begin{array}{l}\text { SMAN 1, SMAN 6, SMAN 7, SMAN 8, } \\
\text { SMAN 9, SMAN 10, SMAN 12, SMAN } \\
\text { 13, SMAN 16, SMA Pertiwi 1, SMA, } \\
\text { Pertiwi II, SMA Kartika } 1-5 \text {, SMA } \\
\text { Pembangunan LAB UNP, SMA } \\
\text { DONBOSCO, SMA Adabiah I, SMA } \\
\text { Adabiah II, SMA PGRI I, SMA Andalas, } \\
\text { MAN 1, MAN } 2\end{array}$ & 21 & $72,41 \%$ \\
\hline 12 & Donor Darah & $\begin{array}{l}\text { SMAN 1, SMAN 4, SMAN 6, SMAN 9, } \\
\text { SMAN 10, SMAN 13, SMAN 16, SMA } \\
\text { Pertiwi 1, SMA, Pertiwi II, SMA Kartika } 1 \\
-5 \text {, SMA DONBOSCO, SMA PGRI I, }\end{array}$ & 18 & \\
\hline
\end{tabular}




\begin{tabular}{|c|c|c|c|c|}
\hline \multirow[b]{3}{*}{13} & \multirow[b]{3}{*}{ Tim Medis } & \multicolumn{3}{|l|}{$\begin{array}{l}\text { SMA Andalas, SMKN 2, SMKN 8, } \\
\text { SMAK Padang, MAN 1, MAN 2, }\end{array}$} \\
\hline & & $\begin{array}{l}\text { SMAN 1, SMAN 3, SMAN 4, SMAN 6, } \\
\text { SMAN 7, SMAN 8, SMAN 9, SMAN 10, } \\
\text { SMAN 12, SMAN 13, SMAN 16, SMA } \\
\text { Pertiwi 1, SMA, Pertiwi II, SMA Kartika } 1 \\
\text { - 5, SMA Pembangunan LAB UNP, SMA } \\
\text { DONBOSCO, SMA Adabiah I, SMA } \\
\text { Adabiah II, SMA PGRI I, SMA Andalas, } \\
\text { SMKN 2, SMKN 6, SMKN 8, SMKN 9, } \\
\text { SMAK Padang, MAN 1, MAN 2, SMKN I }\end{array}$ & & \\
\hline & & Sumbar & 29 & $100 \%$ \\
\hline 14 & Bakti Sosial & $\begin{array}{l}\text { SMAN 1, SMAN 3, SMAN 4, SMAN 6, } \\
\text { SMAN 7, SMAN 8, SMAN 9, SMAN 10, } \\
\text { SMAN 12, SMAN 13, SMAN 16, SMA } \\
\text { Pertiwi 1, SMA, Pertiwi II, SMA Kartika } 1 \\
\text { - 5, SMA Pembangunan LAB UNP, SMA } \\
\text { DONBOSCO, SMA Adabiah I, SMA } \\
\text { Adabiah II, SMA PGRI I, SMA Andalas, } \\
\text { SMKN 2, SMKN 6, SMKN 8, SMKN 9, } \\
\text { SMAK Padang, MAN 1, MAN } 2\end{array}$ & 28 & $96,55 \%$ \\
\hline & Pertolongan & $\begin{array}{l}\text { SMAN 1, SMAN 3, SMAN 4, SMAN 6, } \\
\text { SMAN 7, SMAN 8, SMAN 9, SMAN 10, } \\
\text { SMAN 12, SMAN 13, SMAN 16, SMA } \\
\text { Pertiwi 1, SMA, Pertiwi II, SMA Kartika } 1 \\
\text { - 5, SMA Pembangunan LAB UNP, SMA } \\
\text { DONBOSCO, SMA Adabiah I, SMA } \\
\text { Adabiah II, SMA PGRI I, SMA Andalas, } \\
\text { SMKN 2, SMKN 6, SMKN 8, SMKN 9, } \\
\text { SMAK Padang, MAN 1, MAN 2, SMKN I }\end{array}$ & & \\
\hline 15 & Pertama & Sumbar & 29 & $100 \%$ \\
\hline
\end{tabular}

Sumber: Analisa Pribadi, 2018

Kegiatan ekstrakurikuler PMR memiliki banyak dampak positif bagi siswa maupun sekolah. Dampak positif bagi siswa yaitu; menambah pengetahuan dan pengalaman anak dalam kegiatan kepalangmerahan, menumbuhkan keberanian anak untuk memberikan pertolongan pertama ketika terjadi kecelakaan, mengubah persepsi anak-anak untuk tidak takut ketika ada ambulans yang melintas, menumbuhkan kepedulian sosial anak melalui bakti sosial maupun gotong royong, dan kegiatan PMR sebagai wadah untuk anak memperoleh prestasi. (Pratomo, Dani $2018: 6$ ).

Tabel 5. Jumlah Status PMR berdasarkan Tingkatan PMR di Kota Padang

\begin{tabular}{cccc}
\hline \multirow{2}{*}{ No. } & Tingkatan PMR & \multicolumn{2}{c}{ Status } \\
\cline { 3 - 4 } & Aktif & $\begin{array}{c}\text { Tidak } \\
\text { Aktif }\end{array}$ \\
\hline 1. & SMP/MTs & 15 & 8 \\
\hline 2. & SMA/MAN/SMK & 29 & 5 \\
\hline & Jumlah & $\mathbf{4 4}$ & $\mathbf{1 3}$ \\
\hline
\end{tabular}

Sumber: Hasil Olahan Data Penelitian, 2018 
Berdasarkan hasil survey lapangan, adapun sekolah yang kegiatan PMRnya masih aktif pada tingkat SMP/MTs sebanyak 15 PMR, dan untuk PMR dengan status tidak aktif sebanyak 8 PMR yang ada di Kota Padang.

Adapun kegiatan PMR pada Sekolah Menengah Pertama di Kota Padang terdiri dari 9 kegiatan, yaitu : PAB, diklat, latihan gerakan, Mubes, pelantikan pengurus, latihan mingguan, kepemimpinan, kesiapsiagaan bencana, dan PK. Adapun sekolah yang melaksanakan kegiatan ini terdiri dari 15 sekolah yang kegiatan PMR nya masih aktif.

Hasil presentase dari kegiatan PMR yang aktif pada tingkat SMP di Kota Padang ; PAB 100\%, diklat $100 \%$, latihan gerakan $100 \%$, Mubes $100 \%$, pelantikan pengurus $100 \%$, latihan mingguan $100 \%$, kepemimpinan $100 \%$, kesiapsiagaan bencana $100 \%$, dan PK $100 \%$. Dari hasil persentase tersebut dapat disimpulkan bahwa kegiatan PMR pada tingkat SMP semuanya sama. Seluruh sekolah yang memiliki PMR yang masih aktif menjalankan semua kegiatan tersebut.

Sementara itu ada beberapa sekolah di tingkat SMP yang memiliki kegiatan PMR namun tidak berjalan semestinya. Sekolah sekolah yang memiliki PMR yang tidak aktif tersebut tidak memiliki kegiatan biasanya disebabkan karena tidak memiliki fasilitator. Sehingga mereka tidak melakukan kegiatan - kegiatan yang seharusnya dilakukan. Factor lain yang menyebabkan tidak aktif nya kegiatan PMR pada tingkat SMP karena dari pihak sekolah itu sendiri yang kurang mendukung akan adanya kegiatan PMR tersebut. Dari masalah - masalah tersbut telah menghambat kegiatan PMR itu sendiri dari yang biasanya aktif menjadi tidak aktif lagi.

Berdasarkan hasil survey lapangan, jumlah sekolah yang kegiatan PMRnya masih aktif pada tingkat SMA/MA/SMK di Kota Padang sebanyak 29 PMR dan status PMR tidak aktif sebanyak 5 PMR di Kota Padang.

Hasil kegiatan diperoleh berdasarkan hasil survey di lapangan. Adapun kegiatan PMR pada tingkat Sekolah Menengah Atas adalah sebgai berikut: Pendaftaran Anggota Baru (PAB), Diklat, latihan pendalaman, MUBES, pelantikan pengurus, pelantikan anggota, Training Dasar Organisasi (TDO), lomba OASIS, lomba JUMBARA, latihan gabungan, simulasi gabungan, donor darah, tim Medis, Bakti sosial, dan pertolongan pertama. Adapun sekolah yang melaksanakan kegiatan ini terdiri dari 15 sekolah yang kegiatan PMR nya masih aktif.

Hasil persentase kegiatan PMR pada tingkat SMA dapat diketahui bahwa sekolah yang memiliki PMR yang melaksanakan kegiatan PAB 30 sekolah dengan 
persentase $88 \%$, Sekolah yang melaksanakan kegiatan diklat terdiri dari 29 sekolah dengan persentase $85 \%$, latihan pendalaman sebanyak 26 sekolah dengan persentase $76 \%$, Mubes terdiri dari 29 sekolah dengan persentase $85 \%$, Pelantikan Pengurus 30 sekolah dengan persentase $88 \%$, pelantikan anggota 29 sekolah dengan persentase $85 \%$, TDO 24 sekolah dengan persentase $71 \%$, Lomba Oasis 27 sekolah dengan persentse $79 \%$, lomba jumbara 28 sekolah dengan persentase $82 \%$, latihan gabungan 21 sekolah dengan tidak aktif tersebut tidak memiliki kegiatan biasanya disebabkan karena tidak adanya fasilitator, dan juga untuk sekolah - sekolah yang jauh kurang terjangkau oleh pelatinya, sehingga lama - kelamaan kegiatan PMR yang biasanya berjalan aktif tidak aktif lagi. Selain itu dukungan dari pihak sekolah yang kurang terhadap ekskul PMR ini juga menjadi penyebab matinya kegiatan PMR di tingat SMA.

Jika di bandingkan dengan sekolah tingkat SMP, kegiatan PMR yang berjalan di sekolah tingkat SMA lebih banyak yang aktif dan juga dari segi kegiatannya pada Sekolah Menengah Atas lebih banyak daripada sekolah tingkat SMP.

\section{KESIMPULAN}

Pada tingkat Sekolah

Menengah Pertama terdapat 23 sekolah yang memiiki PMR. Sedangkan pada Sekolah Menengah persentase $79 \%$, simulasi gabungan 21 sekolah dengan persentase $62 \%$, donor darah 18 sekolah dengan persentase $53 \%$, tim medis 30 sekolah dengan persentase $88 \%$, bakti social 29 sekolah dengan persentase $85 \%$. dan yang terakhir pertolongan pertama terdiri dari 30 sekolah dengn persentase $88 \%$.

Sementara itu ada beberapa sekolah di tingkat SMA yang memiliki kegiatan PMR namun tidak berjalan semestinya. Sekolah sekolah yang memiliki PMR yang

Atas (SMA), terdapat 34 sekolah yang memiliki PMR..

Sekolah pada tingkat SMP yang kegiatan PMR nya aktif terdiri dari 15 sekolah dan 8 sekolah yang tidak aktif kegiatannya. Sedaangkan pada tingkat SMA, terdapat 29 sekolah yang kegiatan PMR nya aktif, dan 5 sekolah yang kegiatan PMRnya tidak aktif.

Melalui kegiatan Palang Merah Remaja, proses penyerapan nilai-nilai kemanusiaan dapat dicerna oleh siswa dengan rasa, hati nurani, akal dan kehendaknya untuk berbuat baik. Sehingga dengan pengelolaan jiwanya, siswa mempunyai sikap dan perbuatan yang dapat menjunjung tinggi harkat dan martabat manusia (Prahesty, Reren Eko 2016: 3). 


\section{DAFTAR PUSTAKA}

Dani Pratomo. 2018. Pelaksanaan Kegiatan Ekstrakurikuler Palang Merah Remaja Unit 74 Sd Negeri Bhayangkara. 96 Jurnal Pendidikan Guru Sekolah Dasar Edisi 2 Tahun ke-7 2018. Hal 6

Husein, Rahmad. 2006. "Konsep Dasar Sistem Informasi Geografis". Komunitas eLearning Ilmu Komputer. Yogyakarta: Ilmu Computer.Com

Redy Octama. 2012. Pengaruh Intensitas Kegiatan Ekstrakurikuler Palang Merah Remaja (PMR) Terhadap Perubahan Sikap Sosial Siswa. Jurnal, hal 3

Reren Eko Prahesty. 2016. Peran Ekstrakurikuler Palang Merah Remaja Dalam
Membentuk Sikap Tolong Menolong Siswa Di Smpn 5 Sidoarjo. Jurnal Kajian Moral dan Kewarganegaraan. Volume 01 Nomor 04 Tahun 2016, 201-215, hal 3

Syaiful Asrori. 2013. Pemetaan Sebaran Sekolah Menegah Atas Negeri Di Kabupaten Lampung Tengah. Jurnal, hal 3.

Tri Wahyuningsih. 2015. Analisis Lokasi dan Pola Sebaran Pasar Modern di Kota Yogyakarta, Kabupaten Sleman dan Bantul. Jurnal Ekonomi Bisnis dan Kewirausahaan 2015, Vol.4, No.2, 157-176, hal 3

www.pmi-pemalang.blogspot.co.id di akses tanggal 25 April 2018. 